\title{
A Marsh Deer Census in Brazil
}

\section{George B. Schaller and José Manuel C. Vasconcelos}

In Mato Grosso, Brazil, the authors found what may be the largest marsh deer population in South America, numbering possibly as many as $\mathbf{7 0 0 0}$ animals. But it is seriously threatened, following three bad breeding seasons, 1975-77, attributable, they suspect, to disease, perhaps brucellosis which is common in the cattle of the area. Heavy flooding has also taken a toll. The marsh deer is already listed in the Red Data Book as a threatened species.

The marsh deer Blastocerus dichotomus is the largest deer in South America, males reaching a height of up to $115 \mathrm{~cm}$ (nearly $4 \mathrm{ft}$ ) at the shoulder. It occurs in northern Argentina, Paraguay, Bolivia, south-east Peru, and in Brazil south of the Amazonian rain forest. Although listed as being vulnerable to extinction, 1 little field work has been done to ascertain its status and current distribution, the survey by Schaller in Argentina ${ }^{4}$ being one exception.

In 1976, we began an investigation into the status of marsh deer in Brazil, surveying first the animals in reserves. Padua ${ }^{2}$ lists marsh deer as occurring in the Araguaia, Chapada dos Veadeiros, and Emas national parks of Goias state, and in the Caracará Biological Reserve of Mato Grosso state. But we found that no deer exist in Chapada dos Veadeiros park, that in Emas they are rare, and that they emigrate from the Caracará seasonally. Only Araguaia contains a small but viable population scattered over the park's $4600 \mathrm{sq} \mathrm{km},{ }^{5}$ but this park has so many problems - ranches, Indian claims, poachers-that it is unlikely to maintain its present size. Thus, a species, which at first glance seemed well represented in Brazilian reserves, actually has no secure home in the country.

Concerned with finding an area that would make a good marsh deer reserve, we concentrated on Mato Grosso state, where several deer populations were said to exist, especially in the south-western part called the Pantanal. The state is so large $(1,232,000 \mathrm{sq} \mathrm{km})$ that we had to rely to some extent on second-hand information in our distribution survey. Marsh deer have been reported from the banks of the Paraná and Araguaia Rivers, but we have little information about their current status. Some probably persist along the upper Rio Guaporé, a tributary of the Madeira, even though the area is intensively ranched. Farther downstream, along the northern bank of the Guaporé in the territory of Rondonia, are huge marshes covering a total area of nearly $10,000 \mathrm{sq}$ $\mathrm{km}$, and on these the deer may still be relatively common, judging by the fact that we saw three on each of the two occasions we briefly sampled an area from the air. There are isolated marshes, ranging in size from a few to many square kilometres, bordering the Ronura, Steinem, Auaia, Curisevo, and other tributaries of the Rio Xingu, and we saw five deer on a large marsh near the confluence of the Ronuro and Steinem during a survey flight, which included 25 minutes of scanning at low altitudes. However, the status of the deer in the upper Rio Xingu, as well as the upper Rio Verde, a tributary of the Tapajos to the west, remains unknown. Further work will no doubt reveal additional populations in northern Mato Grosso between the town of Cuiabá and the southern limit of the rain forest.

Most deer habitat in the state consists of relatively narrow strips of swamp 


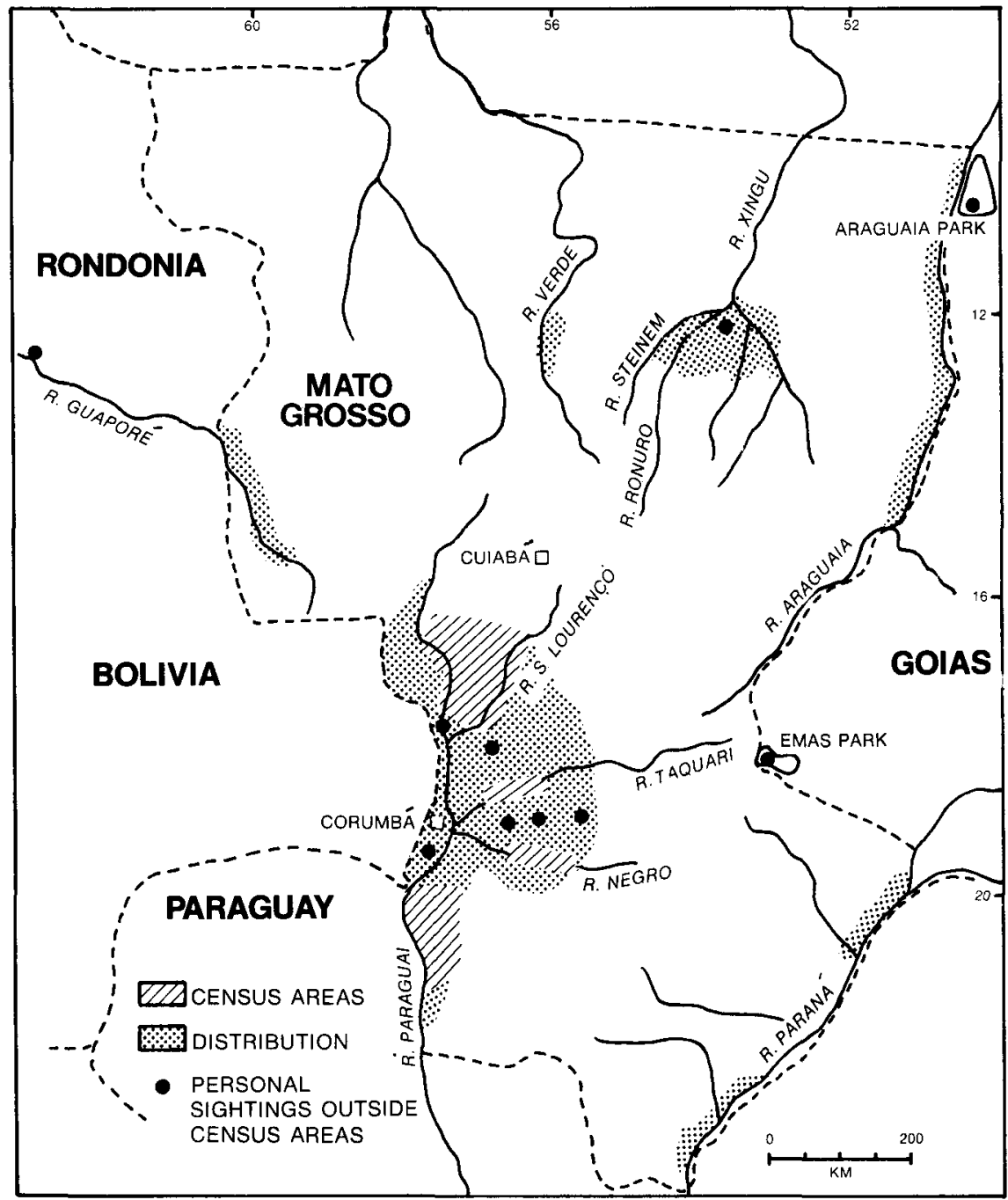

APPROXIMATE DISTRIBUTION of marsh deer in Mato Grosso

along rivers. But part of the Pantanal, a vast plain of some $100,000 \mathrm{sq} \mathrm{km}$ bordering Bolivia and Paraguay, consists of huge marshes and seasonally flooded grasslands whose expanses are broken by thorny thickets, stands of palm, and patches of semi-deciduous forest; there are numerous ponds clogged with water hyacinths, and streams meander sluggishly over the landscape before joining the Rio Paraguai. Our preliminary survey in 1976 had revealed a sizable deer population in the Pantanal, and in 1977 we returned to census it.

\section{Distribution and Numbers in the Pantanal}

Only parts of the Pantanal represent good deer habitat. Marsh deer prefer to be in or near standing water not more than $60 \mathrm{~cm}$ (2ft) deep, with low cover such as reeds, or bunch grasses nearby; they avoid dense forest. In the Pantanal water levels change not only seasonally but also annually. In the rainy season, from November to March, the Rio Paraguai and its tributaries flood the surround- 


\begin{tabular}{lrrrrr}
\hline Area & $\begin{array}{r}\text { Size of } \\
\text { sample } \\
\text { area/sq km }\end{array}$ & $\begin{array}{r}\text { Percent of } \\
\text { total area } \\
\text { covered by } \\
\text { transects }\end{array}$ & $\begin{array}{r}\text { Marsh } \\
\text { deer seen } \\
\text { in transect } \\
\text { strips }\end{array}$ & $\begin{array}{r}\text { Number } \\
\text { sq km } \\
\text { per deer }\end{array}$ & $\begin{array}{r}\text { Total } \\
\text { calculated } \\
\text { population }\end{array}$ \\
\hline N. Pantanal & 14,000 & 7.6 & 281 & 3.8 & 3684 \\
Rio Taquari & 600 & 11.3 & 4 & 17.0 & 35 \\
Rio Negro & 1,200 & 10.1 & 29 & 4.2 & 286 \\
S. Pantanal & 10,000 & 2.5 & 6 & 42.0 & 238 \\
\hline
\end{tabular}

ing plains, and retreat to their beds in the dry months, so that the deer must shift their ranges constantly in order to keep to their preferred water level; thus they are widely dispersed at the height of the floods and increasingly concentrated near rivers and sloughs as the waters recede. During relatively dry years, as in the 1960s, seasonal shifts may be short, but during heavy floods virtually all pastures and forests in low-lying areas are inundated, and the deer may have to travel more than $50 \mathrm{~km}$ to find suitable habitat. An exceptionally high flood occurred in 1974, and large tracts of former deer range were still submerged in 1977.

The marsh deer's foxy-red coat and preference for open habitats makes it highly conspicuous from above, and thus one of the few South American mammals that can profitably be censused from a plane. Since an aerial census of the whole Pantanal was not feasible, we employed a stratified sampling method. Areas of suitable deer habitat noted on survey flights, were selected for censusing, the intensity of coverage depending on deer numbers. In the northern Pantanal we plotted deer distribution during 7 flight-hours in July 1976 and 6.5 hours in April 1977, and then censused for 12 hours in September 1977. In the central and southern Pantanal we surveyed and censused for 7 hours in October 1977. Our flying speed in the north was about $180 \mathrm{~km}$ per hour, and in the other parts $215 \mathrm{~km}$ per hour. The aerial transects consisted of flying along chosen lines, usually at an altitude of $100 \mathrm{~m}$, with four observers including the pilot, counting all animals within a sample of about $250 \mathrm{~m}$ on each side of the plane, giving a strip width of $0.5 \mathrm{~km}$. Deer outside the sample strip were noted but not included in the calculations. Although various biases are inherent in aerial sampling, ${ }^{3}$ we believe that our estimates are of the correct order of magnitude.

We saw 340 deer inside our sample strips and 102 outside for a total of 442 .

In the northern Pantanal we censused a tract of $14,000 \mathrm{sq} \mathrm{km}$ lying mainly between the São Lourenço and Paraguai rivers. To the north and north-west of this tract was forest too dense or too dry for deer; to the south and south-west were swamps too deeply flooded for deer. Our flight pattern was generally eastwest along parallel strips 6 to $9 \mathrm{~km}$ apart. The total of 281 deer, or one deer per $3.8 \mathrm{sq} \mathrm{km}$, seen (Table 1) were not, of course, evenly distributed. Sometimes after flying over good habitat for many kilometres without seeing a deer, a concentration of 15 to 20 was seen. Our calculated total for the whole tract was 3684 deer. Some animals also survive outside the censused area, especially toward the west and north-west, bringing the estimated total for the northern Pantanal to at least 4000 .

The central Pantanal, from near the eastern bank of the São Lourenço south to the Corumbá-Campo Grande road, has relatively little deer habit. The flood 


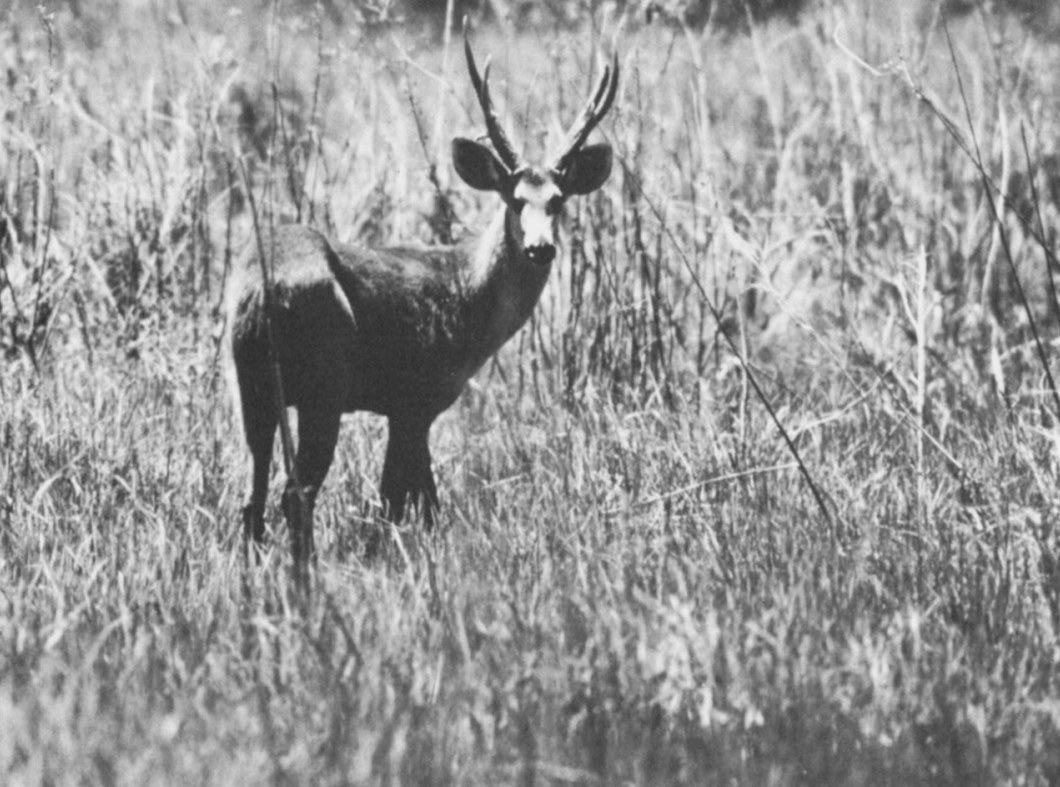

ADULT MALE MARSH DEER in the Pantanal, showing the short massive antlers of this deer. Opposite: Female in the typical tall swampy grasslands of the Pantanal G.B. Schaller

plains of the Rio Paraguai are currently submerged, sometimes for over $30 \mathrm{~km}$ from the banks, and the woodlands and pastures on higher ground to the east have few permanent water sources. Although an occasional deer may be encountered in any isolated body of water, concentrations occur mainly in the swamps near rivers and by permanent lakes with marshy borders. The two main rivers in the area are the Taquari and Negro, and we censused the deer habitat in both drainages (Table 1). The Taquari had few deer, but the density along the Negro was comparable to that of the northern Pantanal with a calculated 286 deer inhabiting $1200 \mathrm{sq} \mathrm{km}$. Between the rivers forest covers most of the terrain, but about $50 \mathrm{~km}$ north of the Rio Negro is a mosaic of forest, pastures, and lakes over which we made a transect flight of $115 \mathrm{~km}$. We saw 14 deer, and the area may contain at least 200 . Our limited surveys suggest around 800 deer in the central Pantanal.

Various informants told us that many deer survived in the southern Pantanal, the large flood plains of the Rio Paraguai bordering Paraguay. We flew east-west transects between the river and high ground, starting at Forte Coimbra in the north and ending at Fuerto Olimpo in the south. The whole region was monotonously covered with flooded pastures and stands of Copernicia palms, and we saw virtually no wildlife. Only 6 deer were tallied. The calculated total for the survey area was 238 , and our estimate for the whole southern Pantanal is 350, a paucity which cannot be explained as due to lack of suitable habitat.

The censuses and estimates thus revealed about 5150 marsh deer. Admittedly our coverage of several parts was cursory. Isolated small populations persist in various localities, as, for example, south of Corumbá between the Rio Paraguai and the Bolivian border, some of which eluded our survey. We therefore suggest a population estimate of 5000 to 6000 , possibly as many as 7000 , in the Pantanal.

It is good news that marsh deer are still moderately abundant in the Pantanal; the bad news is that the population has serious problems.

Within our transect strips, we tried to age and sex each deer although some animals had to remain unclassified because they were partially hidden or 

rest were in groups of two to four. Among the 27 pairs were 12 composed of a male and female, 3 of two females, 2 of two males, 4 of a female with young, and 6 of unidentified pairs. Other samples showed similar group structures. These figures reveal not only that marsh deer tended to be asocial, but also that most females were alone, accompanied neither by a young nor a yearling. We speculate that the cause of the reproductive failure in the years 1975, 1976 and 1977 was brucellosis or spontaneous abortion, a disease which is common in the Pantanal cattle and which, according to the ranchers, has been particularly severe since the floods of 1974 .

During the north Pantanal census we tallied three deer that had just died, apparently of disease. Extrapolated to the whole tract, some 39 deer had succumbed during the previous few days. Earlier, in April, we had also spotted a dead deer, and a pilot mentioned that he had seen several. These animals died most likely of foot-and-mouth disease or of a babesiosis-like infection, both of which are prevalent in the local cattle.

An unknown number of deer have died of starvation in the floods. Those that fail to retreat from the rising waters may become marooned on fragments of high ground. In February 1977 one of us (JMV) saw an aggregation of 11 deer and another of 16 in such a situation. Being both grazers and browsers, marsh deer are well adapted to surviving in a small area, but if the high waters linger too long, or if competition for the limited forage with similarly stranded cattle is severe, they may succumb.

Disease is decimating the adult marsh deer in the northern Pantanal and starvation has taken a toll where floods have been unusually heavy. And throughout the Pantanal the annual increment of fawns is so small, again probably due to disease, that it cannot maintain the populations. All evidence indicates that the marsh deer have declined drastically since 1974 and that the populations are continuing to crash.

\section{Conservation}

We are dismayed to report on perhaps the largest marsh deer population in South America and at the same time to predict its rapid decline to an undetermined but low level. Nothing can be done to halt the decimating effect of the presumed diseases, and conservation measures must now be directed towards ensuring that the remnants survive. It is already illegal to kill marsh deer in Mato Grosso, although regulations are seldom enforced. In the Pantanal, hunting for trophies, meat, and hides continues on some ranches and near towns such as Corumbá. So far the deer have been little molested in their major stronghold, the northern Pantanal, where on the large ranches neither meat nor hides are coveted. But the construction of the Transpantanal Highway, which already penetrates more than $100 \mathrm{~km}$ into the Pantanal from the north, will open the marshes to motorised poachers, as well as facilitate the movement of cattle with their diseases. The Caracará Biological Reserve bordering our northern census block is wholly submerged during floods, but the government plans to make it a suitable deer reserve by buying two adjoining ranches with high ground. However, the propensity of deer to shift with changing water levels makes it virtually impossible to contain a large population within a limited reserve. The co-operation of the local ranchers is also required in any conservation programme. For the present, a need is to monitor the populations as they decline, and subsequently, it is hoped, increase, and this we plan to do at intervals. 


\section{Acknowledgments}

Our research is supported mainly by the New York Zoological Society, the National Science Foundation, the National Geographic Society, and the Instituto Brasileiro de Desenvolvimento Florestal. Funds for flying were generously provided by the Fundaçáo Brasileira para a Conservaçáo da Natureza. Paulo Benedito Siqueira helped us in various ways, and S. Barrett, D. Assoreira, and $\mathbf{R}$. Best capably participated in some of the censusing and surveying.

\section{References}

1. COWAN, I. and HOLLOWAY, C. 1973. Threatened deer of the world: conservation status. Biol. Cons. 5: 243-250

2. PADUA, M. n.d. Parques nacionais e reservas equivalentes. Instituto Brasileiro de Desenvolvimento Florestal, Brasilia. 35pp.

3. PENNYCUICK, C. and WESTERN, D. 1972. An investigation of some sources of bias in aerial transect sampling of large mammal populations. E. Afr. Wildl. F. 10: 175-191

4. SCHALLER, G. 1976. Report on a wildlife survey in northern Argentina and in the Emas National Park, Brasil. Mimeographed report to World Wildlife Fund, Morges. $17 \mathrm{pp}$.

5. SCHALLER, G. and VASCONCELOS, J. 1976. The status of some large mammals in Goias and Mato Grosso states of Brazil. Mimeographed report to Instituto Brasileiro de Desenvolvimento Florestal, Brasilia. 9pp.

Dr George B. Schaller, New York Zoological Society, Bronx Park, Bronx, New York 10460; J.M.C. Vasconcelos, Instituto Brasileiro de Desenvolvimento Florestal, Palacio do Desenvolvimento, Brasilia, Brazil.

\section{Visit to a Surinam Turtle Reserve}

\section{T.H. Bassett}

I visited the Galibi Nature Reserve in Surinam, probably one of the most easily accessible turtle reserves for visitors in the world, in the first week of June 1978, accompanied by the resident warden, George Plak.

The first night we saw two leatherback turtles Dermochelys olivacea nesting, one of which obligingly laid its eggs for us by flashlight. The second night we watched olive ridley and green turtles laying, and the following morning I saw four green turtle nests being dug out and the eggs placed in foam boxes for hatching. Green turtle eggs laid below spring-tide high-water level are removed from the nests and placed in foam boxes with a layer of sand below and a nylon cloth with a layer of sand on top. The nylon is important for retaining warmth. The boxes are stored in a corrugated iron incubator house and the hatching rate is high. The baby turtles are then transferred to another foam box for 36 hours with clean sand until they absorb and clean the yolk sac.

On a routine patrol with the beach guards I saw nests of leatherback and olive ridley Lepidochelys olivacea, which were below the spring tide level, being located by probing, and the eggs dug out, counted and put into a fresh pit above the highest water mark. The eggs take two months to hatch and would be chilled and killed by the cooling of the spring tides. At $7.00 \mathrm{a} . \mathrm{m}$. I had the good fortune to see a leatherback haul out and start to prepare its nest hole. But as the sun grew hotter it had to abandon the attempt. At $5.30 \mathrm{p} . \mathrm{m}$. in the late afternoon we took the hatchlings from the hatchery and released them a mile out to sea.

The turtle nesting season is from January to July. Reservations are made with Stinasu (Stichting Natuur Behod Suriname), c/o Surinam Forest Service, P.O. Box 436, Paramaribo, Surinam. 